\title{
Spatial distribution of four sympatric owl species in Carpathian montane forests
}

\author{
Priestorová distribúcia štyroch sympatrických druhov sov v karpatských horských lesoch
}

\author{
Karol ŠOTNÁR, Ján OBUCH, Samuel PAČENOVSKÝ \& Benjamín JARČUŠKA
}

\begin{abstract}
Knowledge about spatial distribution of owl species is important for inferring species coexistence mechanisms. In the present study, we explore spatial patterns of distribution and habitat selection of four owl species - Eurasian pygmy owl (Glaucidium passerinum), boreal owl (Aegolius funereus), tawny owl (Strix aluco) and Ural owl (Strix uralensis) - ranging in body mass from $50 \mathrm{~g}$ to $1300 \mathrm{~g}$, with sympatric occurrence in temperate continuous montane forests in the Vel'ká Fatra Mts., Western Carpathians, central Slovakia. Locations of hooting owl males were surveyed between $2009-2015$ in an area of $317 \mathrm{~km}^{2}$. Spatial point pattern analysis was used for analysis of owl distribution. Random patterns of owls' spatial arrangement dominate at both intra- and interspecific levels within the studied area. Only intraspecific distribution of pygmy owls and interspecific distribution of Ural owls toward tawny owls exhibited positive associations. This discrepancy with other studies can be explained in terms of pygmy owls' preference for high-quality nest sites and/or spatial clustering in their prey distribution, and due to aggressive behaviour of dominant Ural owls toward subdominant tawny owls, respectively. Moreover, we found considerable overlap in habitat preferences between owl species, considering stand age, stand height, tree species richness, distance to open area, elevation, slope, percentage of coniferous tree species and position on hillslope, although pygmy owls were not registered in pure broadleaved stands, Ural owls were not registered in pure coniferous stands, and boreal and Ural owls were more common on slope summits and shoulders than tawny and pygmy owls. The observed patterns of spatial arrangement might suggest developed coexistence mechanisms in these owl species; differences between studies may indicate complex interactions between intra- and interspecific associations and habitat quality and quantity, food availability and owl species involved in those interactions on a landscape scale.
\end{abstract}

\begin{abstract}
Abstrakt: Poznatky o priestorovej distribúcii rozličných druhov sov sú dôležité pre pochopenie mechanizmov spolužitia druhov. V tejto štúdii skúmame priestorový vzor distribúcie a výber habitatu u štyroch druhov sov - kuvička vrabčieho (Glaucidium passerinum), pôtika kapcavého (Aegolius funereus), sovy obyčajnej (Strix aluco) a sovy dlhochvostej (Strix uralensis), dosahujúcich hmotnost' od 50 do 1300 g, so sympatrickým výskytom v súvislých horských lesoch mierneho pásma v pohorí Vel'ká Fatra (Západné Karpaty, Slovensko). V rokoch 2009 - 2015 boli na území s rozlohou 317 km² mapované miesta výskytu teritoriálne sa ozývajúcich samcov sov. Pre analýzu distribúcie sov bola použitá priestorová bodová analýza. Náhodný charakter priestorovej distribúcie sov prevažoval na skúmanej ploche na vnútrodruhovej aj medzidruhovej úrovni. Pozitívna asociácia sa zistila len pri vnútrodruhovej distribúcii kuvičkov vrabčích a medzidruhovej distribúcii sov dlhochvostých voči sovám obyčajným. Táto nezhoda s inými štúdiani sa môže vysvetlit' preferenciou kuvičkov k hniezdnym lokalitám vysokej kvality a/alebo v dôsledku priestorového zhlukovania koristi kuvičkov, a agresívnym správaním dominantnej sovy dlhochvostej voči subdominantnej sove obyčajnej. Navyše, našli sme významný prekryv v habitatových preferenciách - veku porastu, zastúpení drevín v poraste, vzdialenosti k otvoreným plochám, nadmorskej výške, sklone svahu, zastúpení ihličnanov a polohe vo svahu - medzi jednotlivými druhmi sov, avšak kuvičky vrabčie neboli registrované v čistých listnatých porastoch, sovy dlhochvosté neboli registrované $\mathrm{v}$ čistých ihličnatých porastoch, pôtiky kapcavé a sovy dlhochvosté boli bežnejšie v hrebeňovej a podhrebeňovej časti svahov ako kuvičky a sovy obyčajné. Pozorovaný vzorec priestorového rozmiestnenia môže naznačovat' existenciu vyvinutých mechanizmov spolužitia týchto druhov sov; rozdiely medzi jednotlivými štúdiami môžu poukazovat' na zložité vzt'ahy medzi vnútroa medzidruhovými asociáciami a kvalitou či zastúpením habitatu, dostupnost’ou potravy a druhmi sov zahrnutými v týchto interakciách na krajinnej priestorovej škále.
\end{abstract}

Key words: spatial arrangement, territoriality, habitat characteristics, point pattern analysis

Karol Šotnár, Raptor Protection of Slovakia, Trhová 54, SK-841 01 Bratislava 42, Slovakia.

Ján Obuch, Botanical Garden of Comenius University, SK-038 15 Blatnica, Slovakia.

Samuel Pačenovský, State Nature Conservancy of the Slovak Republic, Tajovského 28B, SK-974 01 Banská Bystrica, Slovakia. E-mail: samuel.pacenovsky@sopsr.sk. 
Šotnár K, Obuch J, Pačenovský S \& Jarčuška B: Spatial distribution of four sympatric owl species in Carpathian montane forests

Benjamín Jarčuška, Institute of Forest Ecology, Slovak Academy of Sciences, L'. Štúra 2, SK-960 01 Zvolen, Slovakia. E-mail: benjamin.jarcuska@gmail.com.

Acknowledgements: We are grateful to three reviewers for their comments on the initial drafts of the manuscript and to Andrew J. Billingham for language proofreading. We also thank all our colleagues working in the field for the data from their observations of owls: E. Apfel, M. Apfelová, B. Demovič jun., Z. Masárová, M. Michalčík, J. Moskál', M. Nemčok, A. Oravec, A. Páleš, J. Píš, J. Pokrievková, L. Remeník, P. Šípoš, M. Šmelcer, M. Špilák, K. Takáč, J. Žiak and J. Topercer. BJ was supported by VEGA project 2/0076/19.

\section{Introduction}

Direct and indirect interactions between members of the same species or different species competing for a shared limited resource, expressed as competition, are determinants of population and community structure (Sih et al. 1985, Townsend et al. 2008). Requirements for resources are more similar at intraspecific than at interspecific level, resulting in stronger competition within species than among species (Connell 1983). Those interactions can be more marked when species act simultaneously as predator and competitor for other species at the same or similar trophic level, referred as intraguild predation (Polis et al. 1989, Sergio \& Hiraldo 2008, Lourenço et al. 2014). Intraguild predation as an asymmetrical and size-based phenomenon can affect distribution, abundance and evolution of the species involved (Sih et al. 1985) through reduction of site occupancy, breeding success and survival of the species (Sergio \& Hiraldo 2008, Lourenço et al. 2014). Individuals of the prey species respond to intraguild predation pressure through direct predator avoidance, i.e. spatial and/or temporal segregation, habitat-mediated avoidance, short-term behavioural avoidance (e.g. reduced vocal activity and escape to refugia after predator detection) and resource partitioning (Zuberogoitia et al. 2005, Sergio et al. 2007, Sergio \& Hiraldo 2008, Holm et al. 2016, Jenkins et al. 2019). Predator avoidance must be an effective mechanism in any intraguild predation system to enable long-term coexistence of the intraguild prey with its predator (Sergio et al. 2007, Sergio \& Hiraldo 2008). Non-overlapping patterns of spatial distribution develop among species at higher trophic levels, avoiding aggressive interactions between individuals (intra- and interspecifically), leading to territorial behaviour in predatory birds (Sergio et al. 2003, Vrh \& Vrezec 2006). Territoriality in birds is more often displayed as acoustic communication than as aggressive interaction (König \& Weick 2008). The dominant species has an advantage when occupying the most suitable localities within habitats, as large species are usually dominant in interspecific interactions, outcompeting smaller, subordinate ones, thus dictating their distribution pattern (Vrh \& Vrezec 2006, Sergio et al. 2007, Sergio \& Hiraldo 2008, Rebollo et al. 2017).

We studied four sympatric owl species: Ural owl (Strix uralensis), tawny owl (Strix aluco), boreal owl (Aegolius funereus, also known as Tengmalm's owl) and Eurasian pygmy owl (Glaucidium passerinum). The weight ranges of these owls are 47-83 g (pygmy owl), 90-194 g (boreal owl), 325-716 g (tawny owl) to 5001300 g (Ural owl) (König \& Weick 2008). Their body mass is positively associated with their competitiveness (e.g. Vrezec \& Tome 2004a). Habitat and food preferences of these species overlap to a great extent, but pygmy owls show a high proportion of small birds in their diet (Mikkola 1983, Hagemeijer \& Blair 1997, Marks et al. 1999, Obuch 2011, Kloubec, et al. 2015, Šotnár et al. 2015). Interspecific competition is size-related, i.e. heavier owl species prey upon smaller one(s) (e.g. Mikkola 1976), thus it can be assumed that the smaller the species, the larger the predation risk. Tawny owl and Ural owl pair-bonds last for life, while boreal owl pair-bonding is only seasonal, and pygmy owl pairbonds sometimes last for more than one season. Tawny owls and Ural owls maintain the same territory for many years; the boreal owl is characterized as a sedentary species with irregular wanderings around breeding sites in central Europe (adult females and young birds are especially marked as nomadic; adult males are mostly sedentary) (Kämpfer-Lauenstein \& Lederer 2010, Kloubec et al. 2015); pygmy owl males may use the same territory for up to seven years (König \& Weick 2008). While there are some studies assessing patterns of sympatric occurrence of two or three of these species (e.g. Lundberg 1980, Hakkarainen \& Korpimäki 1996, Vrezec \& Tome 2004a, b, Suhonen et al. 2007, Kajtoch et al. 2015), we are aware of only one study dealing with all four owl species (Kajtoch et al. 2016); however, the sample size in the latter study did not allow all interspecific interactions to be assessed. 
Geographic differences in patterns of coexistence between owl species associated with intraguild predation can be found in the literature. Due to negative interactions, tawny owls select areas free of Ural owls in central Sweden (Lundberg 1980), in the Slovenian Dinaric Alps (Vrezec \& Tome 2004a, b) and the Carpathian foothills in southern Poland (Kajtoch et al. 2015, 2016). No negative spatial interactions (segregation in habitat use) have been found between Ural owls and boreal owls despite their territories overlapping in central Finland (Hakkarainen \& Korpimaki 1996), in the Dinaric Alps (Vrezec \& Tome 2004a) and in Poland (Kajtoch et al. 2015, 2016). While spatial segregation has been observed between tawny owl and boreal owls in the Dinaric Alp forests (Vrezec \& Tome 2004b), no such pattern between these two species was observed in the Polish Carpathian foothills (Kajtoch et al. 2015). Distribution of pygmy owls was not affected by that of Ural owls in the Polish Carpathians (Kajtoch et al. 2016).

Species dynamics are driven by spatial and temporal processes (Fletcher \& Fortin 2018). For this reason, in order to better understand intra- and interspecific spacing behaviour, interactions, territoriality, interference competition and mechanisms of coexistence, we analysed patterns of spatial distribution of the four owl species (Eurasian pygmy owl, boreal owl, tawny owl, and Ural owl) living in sympatry in relatively well-preserved montane forests in part of the Western Carpathians (Vel'ká Fatra Mts. in Slovakia) using point pattern analysis (Baddeley et al. 2015, Fletcher \& Fortin 2018). Studies considering the distribution of sympatric owl species from the spatially-explicit perspective are scarce. In addition, we examined the habitat characteristics at the locations of calling (hooting) males. To date there is a lack of data on the spatial patterns of these four owl species (Sergio \& Hiraldo 2008, Kajtoch et al. 2016).

\section{Material and methods}

\section{$\mathrm{St} u \mathrm{~d}$ y a r e a}

The studied area $\left(48.944^{\circ} \mathrm{N}, 19.086^{\circ}\right.$ E; Fig. 1) is located in central Slovakia, in the Vel'ká Fatra Mts (Western Carpathians), within the Vel'ká Fatra National Park and Special Protection Area. The size of the studied area is $317 \mathrm{~km}^{2}$; elevation ranges from ca. $500 \mathrm{~m}$ to $1596 \mathrm{~m}$ a.s.l. Parent rock consists predominantly of dolomites, limestones and marly limestones (Biely et al. 2002). The relief of the mountain range is quite rugged, with a large elevational range. The relief is characterized by deep valleys with steep slopes, gorges and outcropping rocks. Mean annual temperatures vary between 2.5 and $6.5{ }^{\circ} \mathrm{C}$ (Š́t'astný et al. 2002), and mean total annual precipitation ranges between 750 and $1250 \mathrm{~mm}$ (Faško \& Št'astný 2002). Relatively well-preserved forest (e.g. Mikolás et al. 2019) covers nearly $90 \%$ of the area. The upper tree line was lowered at some places in the past (especially during the Wallachian colonization) and now lies at ca. $1350 \mathrm{~m}$ a.s.l. in this area. Most forest stands have natural species composition (including European beech Fagus sylvatica, silver fir Abies alba, Norway spruce Picea abies, sycamore Acer pseudoplatanus, mountain ash Fraxinus excelsior, larch Larix decidua, Scotch pine Pinus sylvestris, lime Tilia spp., European hornbeam Carpinus betulus), but have been replaced in some places with pure Norway spruce plantations. Within the altitude range 500-1000 m a.s.l. mixed fir-beech forests predominate, spruce-beech-fir forests predominate from 900 to 1300 a.s.l., and mountain coniferous Norway spruce forests dominate from 1250 to 1550 a.s.l. Forest stands are thus mostly mixed, but there are also homogeneous coniferous and deciduous forests. The age of stands is in some places up to 200 years and many stands are more than 100 years old. The best-preserved, unmanaged forests are located mainly in the south-western part of the studied area, where there are several strictly-kept nature reserves. Commerciallymanaged forests predominate in other parts of the studied area. No human settlements are situated inside the study area.

\section{O w 1 i n v e n t o r y}

The owl inventory was carried out by means of acoustic monitoring of hooting males (advertising calls) from survey transects and points. The inventory of the area was performed gradually, in sections (i.e. valleys), from 2009 to 2015, and each valley was surveyed only once. The fact that this owl survey was done in different years should not affect the results, as most owl territories were found to be constant over the years (Kajtoch et al. 2015, Peri 2018a); however philopatry can be influenced by food availability (Korpimäki \& Hakkarainen 2012). Surveys were conducted during the peak period of owl pre-breeding, breeding and post-breeding activities in spring and autumn, from the end of February to the end of April and from September to the beginning of November. In the evenings, we mapped especially at dusk and then ca. two hours after sunset. In the mornings, we started mapping about one hour before sunrise and continued until 9:00 a m. We did not map during 


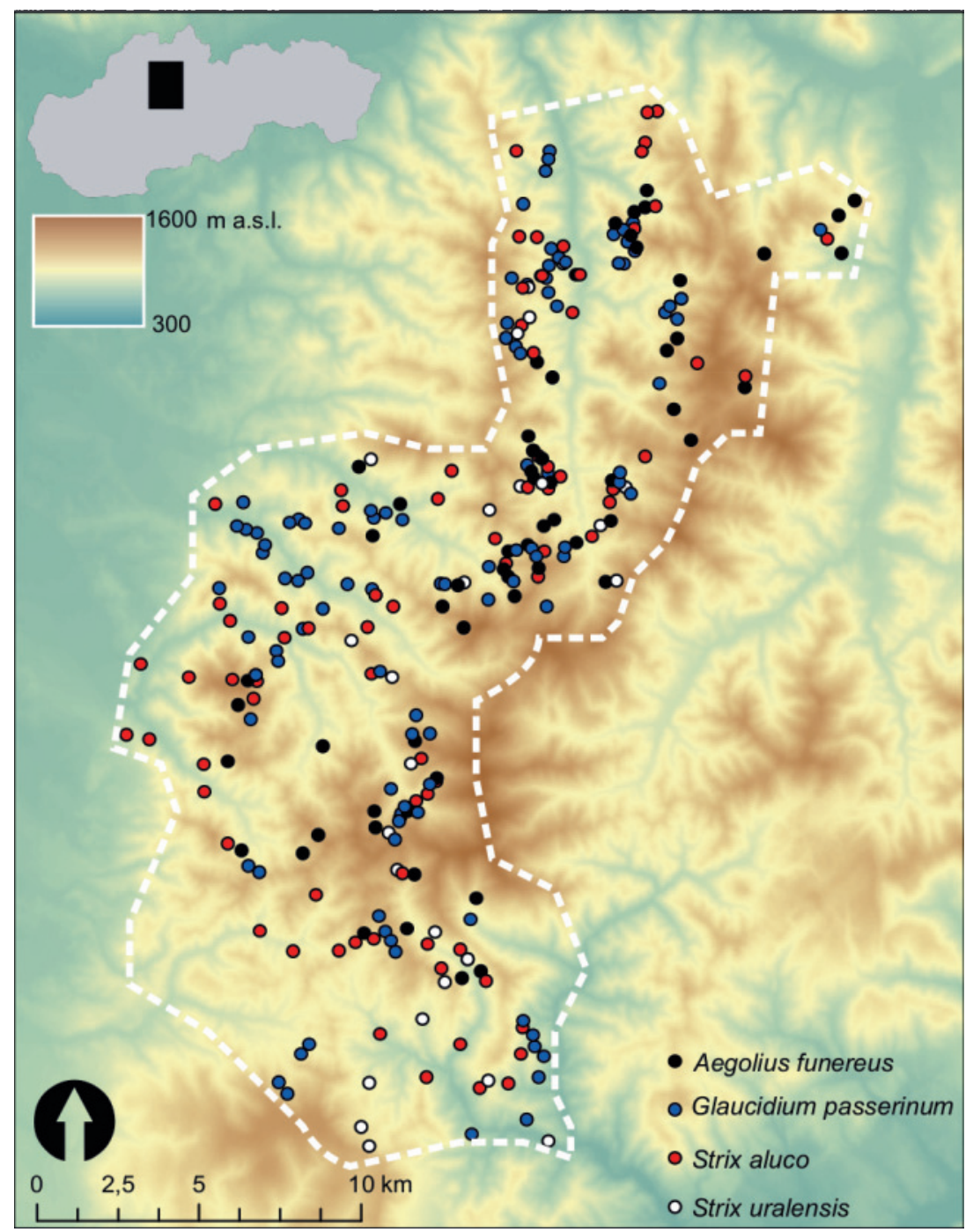

Fig. 1. Study area in the Vel'ká Fatra Mts with the registered four owl species.

Obr. 1. Študované územie vo Vel'kej Fatre s registrovanými lokalitami výskytu štyroch druhov sov.

rain and strong winds. In total we carried out 71 evening or morning visits. We used a combination of transect and point-count methods. Survey points were spaced evenly in the landscape, in forest stands older than 40 years, all between 500-1000 m a.s.1. Each stop including listening lasted for 10-15 minutes. Pygmy owls were provoked by mouth-imitation of their territorial voice. The pygmy owl has different timing of activity compared to the other three species: it has crepuscular activity in the evening and early morning and it is considered as a conspicuous daytime hunter (Marks et al. 1999). For these reasons we provoked it to improve our chances of detecting it during its short periods of crepuscular activity lasting less than one hour in the evening and early morning. We did not use broadcasting of calls of the other three owl species as this could have drawn owls into otherwise unused areas as a reaction to call broadcasts (Kissling et al. 2010). Special emphasis was put on recording simultaneously hooting birds. Locations of calling owls were marked with GPS coordinates.

$\mathrm{H}$ a bitat characterist i c s

We extracted the habitat characteristics of the forest stands in which calling owls were located from the Forestry Geographic Information System (LGIS 2020). The following parameters were extracted: elevation (m a.s.l.), stand age (years), slope (gradient, \%), stand height $(\mathrm{m})$, tree species richness $(\mathrm{n})$, and proportion of coniferous tree species (\%). Location of calling owl on 
hillslope was also assigned ( 0 - toeslope, 1 - footslope, 2 - backslope, 3 - shoulder and summit; after Schoeneberger et al. 2012). Distance to an open area was measured in Google Earth Pro (Google 2020). Open areas were defined as clear-cutted woodland, meadows, pastures, and rock outcrops, with a minimum area of 1 ha.

\section{$\mathrm{D}$ a $\mathrm{t}$ a a n a $1 \mathrm{y} \mathrm{s}$ i s}

We used R 3.6.3 statistical software (R Core Team 2020) for analyses of the data.

To characterize intra- and interspecific spatial distributions of calling owls we calculated the nearest-neighbour distance between calling individuals using the "nndist" function in the R "spatstat" library (Baddeley \& Turner 2005, Baddeley et al. 2015). For more details on the calculations, see Rebollo et al. (2017).

We also used the nearest-neighbour distance distribution function (G-function and multitype (or cumulative or cross-type) G-function) implemented in the "spatstat" library ("Gest" and "Gcross" functions) to analyse the spatial arrangement of four owl species, as it provides a better summary of information than that conveyed by mean nearest-neighbour distances. It allows determining of whether the distribution of individuals is random, regular or clustered. We used Gfunction as it summarises information at shorter range (Baddeley et al. 2015), and the studied owl species are very territorial during spring and autumn (König \& Weick 2008). To test for statistical significance of spatial arrangement (using a hypothesis of complete spatial randomness), we generated an acceptance interval with significance level of $0.4 \%(\mathrm{P} \leq 0.004)$ associated with simulation envelopes of the summary function ("alltypes" function, number of Monte Carlo permutations = 499). We used default edge effect correction. The acceptance interval is the range of values deemed to be not significantly different from the hypothesised value of the target quantity (Baddeley et al. 2015). True (or estimated or observed) values of the cross-type G-func- tion curve above/below the theoretical cross-type Gfunction curve of a completely random point pattern indicate whether more/less points (i.e. owl individuals) were observed within a given radius than what would be expected under complete spatial randomness (aggregation/segregation).

We used analysis of variance (ANOVA) to test for association between species identity of calling owl and habitat characteristics (continuous variables). Because of unequal sample sizes we used one-way ANOVA applying Type III Sums of Squares. Tukey post-hoc testing was used to identify differences between the owl species when the habitat/environmental variable was identified as significant overall. ANOVA and Tukey tests were performed in the "car" package (Fox \& Weisberg 2019). Association between species identity and position on hillslope location was assessed using ordinal logistic regression in the "MASS" library (Venables \& Ripley 2002). McFadden's pseudo- $R^{2}$ was calculated using the "pscl" library (Jackman 2017). Pairwise post-hoc testing was performed using the "pairwiseOrdinalIndependence" function implemented in the "rcompanion" package (Mangiafico 2017) and relying on the "coin" package (Hothorn et al. 2017). The "ggplot2" package (Wickham et al. 2016) was used for plot visualization.

\section{Results}

O v e r v i e w

Overall we registered 274 calling individuals of four owl species in the study area. The most abundant species was pygmy owl, followed by tawny owl and boreal owl, while the least numerous was Ural owl (Table 1). Density of owl species ranged from $0.85 / 10$ $\mathrm{km}^{2}$ (Ural owl) through 1.99/10 $\mathrm{km}^{2}$ (boreal owl) and $2.49 / 10 \mathrm{~km}^{2}$ (tawny owl) to $3.31 / 10 \mathrm{~km}^{2}$ (pygmy owl).

S p a t i a 1 a r range me $\mathrm{nt}$ of ow $1 \mathrm{~s}$ Mean nearest-neighbour distance (NND) between calling owls was $460.4 \pm 21.0 \mathrm{~m}$ (median $=356.1 \mathrm{~m}$ ). Ural

Tab. 1. Mean intraspecific and interspecific nearest-neighbour distances ( \pm standard error) between registered calling locations of Eurasian pygmy owl, boreal owl, tawny owl and Ural owl in the Vel'ká Fatra Mts.

Tab. 1. Priemerné vnútrodruhové a medzidruhové vzdialenosti k najbližšiemu susedovi ( \pm stredná chyba) medzi registrovanými volacími miestami kuvičkov vrabčích, pôtikov kapcavých, sov obyčajných a sov dlhochvostých vo Vel'kej Fatre.

\begin{tabular}{lrcccc}
\hline & \multicolumn{5}{c}{$\begin{array}{c}\text { mean nearest-neighbour distances } \pm \text { standard error (m) / } \\
\text { priemerná vzdialenost' k najbližšiemu susedovi }\end{array}$} \\
species / druh & $\mathbf{n}$ & to / k A. funereus & to / k G. passerinum & to / k S. aluco & to / k S. uralensis \\
\hline Aegolius funereus & 63 & $951.7 \pm 76.5$ & $782.5 \pm 76.7$ & $851.3 \pm 76.7$ & $2209.2 \pm 260.3$ \\
Glaucidium passerinum & 105 & $1436.2 \pm 127.9$ & $592.9 \pm 54.0$ & $915.1 \pm 62.8$ & $1987.9 \pm 137.4$ \\
Strix aluco & 79 & $1398.9 \pm 129.0$ & $1088.3 \pm 104.7$ & $993.7 \pm 77.9$ & $2341.8 \pm 222.6$ \\
Strix uralensis & 27 & $1690.7 \pm 337.0$ & $1101.9 \pm 172.3$ & $858.5 \pm 143.7$ & $1452.2 \pm 485.9$ \\
\hline
\end{tabular}


owls showed the longest mean intraspecific NND between calling individuals, followed by tawny, boreal and pygmy owls. The longest mean interspecific NND between calling individuals was found from tawny, boreal and pygmy owls to Ural owls ( $2000-2350 \mathrm{~m})$, followed by Ural, pygmy and tawny owls to boreal owls $(\sim 1430-1700 \mathrm{~m})$; Ural and tawny owls to pygmy owls $(\sim 1100 \mathrm{~m})$; pygmy, Ural and boreal owls to tawny owls; and lastly boreal owls to pygmy owls $(\sim 780-910 \mathrm{~m})$ (Table 1).

Global spatial distribution of the owl community had a clustered pattern of distribution in radius up to $100 \mathrm{~m}$ and from ca. $300 \mathrm{~m}$ to $600 \mathrm{~m}$ (Fig. 2). However, the test of spatial arrangement of owl species using the multitype G-function showed that the observed functions fall within the simulation envelope $(\mathrm{P} \leq 0.004)$ for the whole distance range for most inter- and intraspecific associations (Fig. 3). This indicates that individual calling owls are similarly and randomly distributed around each other, that no attraction or repulsion between the birds was present. Only two exceptions were observed: intraspecific positive association among pygmy owls and interspecific positive association between Ural owls and tawny owls (Fig. 3). Individual pygmy owls were closer to each other than would be expected in a random pattern $(\mathrm{P} \leq 0.004)$ within a distance range from 0.3 to $1.0 \mathrm{~km}$. Similarly, distribution of Ural owls toward tawny owls was aggregated within a range from 0.4 to $0.8 \mathrm{~km}$; the opposite was not true however.

Habitat characteristics of o w l s, c a $11 \mathrm{ing} 1 \mathrm{oc}$ at i o n s

We did not find statistically significant differences between the four owl species in terms of stand age, stand height, tree species richness or distance to open areas of their calling locations $(\mathrm{P}=0.147-0.615)$. However, Ural owls called from locations up to $\sim 300 \mathrm{~m}$ from open sites while the other species were registered also at greater distances. The elevation, slope, percentage of coniferous tree species and position on hillslope of calling owls differed statistically significantly between species, but species identity explained only 2 $5 \%$ of variability in these characteristics (Fig. 4). Pygmy owls were observed in stands with the highest proportion of conifers. Ural owls were not registered in pure coniferous stands, and pygmy owls were not registered in pure broadleaf stands. Boreal and Ural owls were more common on slope summits and shoulders than tawny or pygmy owls.

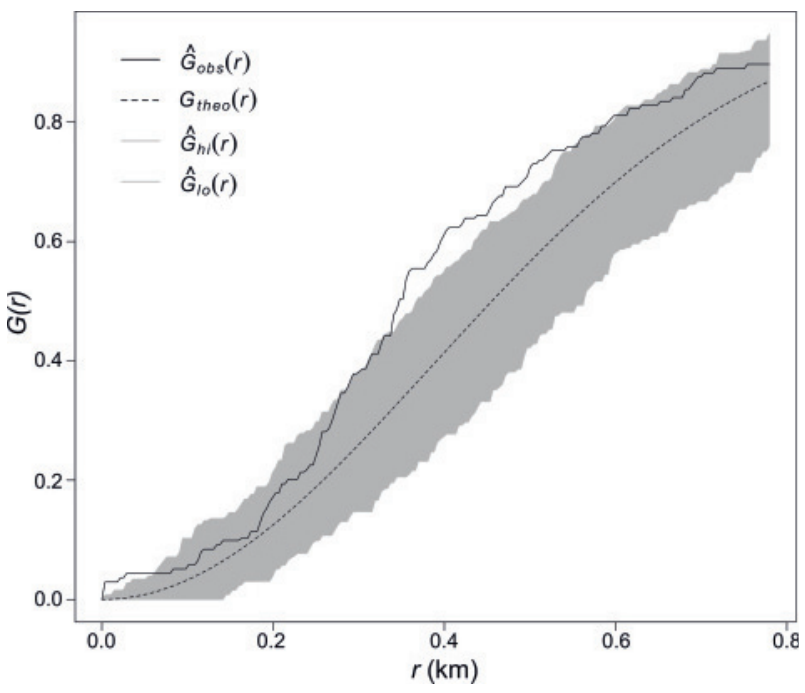

Fig. 2. Overall relationship between nearest-neighbour distance distribution function $(G(r))$ and distances between locations with registered owls $(r$; in $\mathrm{km})$. Continuous line represents the observed function of species records; dashed line indicates theoretical null model expectations; and grey areas indicate the simulation envelopes generated from 499 Monte Carlo simulations under the null hypothesis of complete spatial randomness $(P \leq 0.004)$. Arrangement of points within an area is considered as clustered if the observed function is above the simulation envelope, as regular if the function is below the envelope, and as random if it is inside the envelope.

Obr. 2. Celkový vzt'ah medzi distribučnou funkciou vzdialenosti najbližšieho suseda $(G(r))$ a vzdialenost'ami medzi lokalitami so zaznamenanými sovami $(r, \vee \mathrm{km})$. Súvislá čierna čiara predstavuje pozorovanú funkciu zaznamenaných jedincov sov, prerušovaná čiara predstavuje očakávaný teoretický nulový model a sivé plochy naznačujú simulované obaly vygenerované zo 499 Monte Carlo simulácií pri nulovej hypotéze úplnej priestorovej náhodnosti $(P \leq 0.004)$. Umiestnenie zaznamennaých bodov $v$ priestore je považované za zhlukovité, ak pozorovaná funkcia je pod obalmi, a ako náhodné, ak sa nachádza vo vnútri obalov.

\section{Discussion}

In the montane forests of the Vel'ká Fatra Mts, Western Carpathians, we found a random pattern of spatial arrangement of calling male owls for most intra- and interspecific associations within and between the four owl species, except for (i) intraspecific distribution of pygmy owls, where the calling males were closer than expected at distances from $0.3 \mathrm{~km}$ up to $1 \mathrm{~km}$, and (ii) interspecific distribution of Ural owls toward tawny owls, where Ural owl males were closer to male tawny owls than expected at distances between $0.4 \mathrm{~km}$ to $0.8 \mathrm{~km}$. 
We observed no or only subtle interspecific differences in habitat characteristics of calling owls' locations; their habitat requirements considerably overlapped. However, pygmy owls were not registered in pure broadleaf stands, which is in accordance with most published data on the great preference of this species for coniferous and mixed forests throughout Europe (Marks et al. 1999; Pačenovský 2002a, Henrioux et al. 2003,
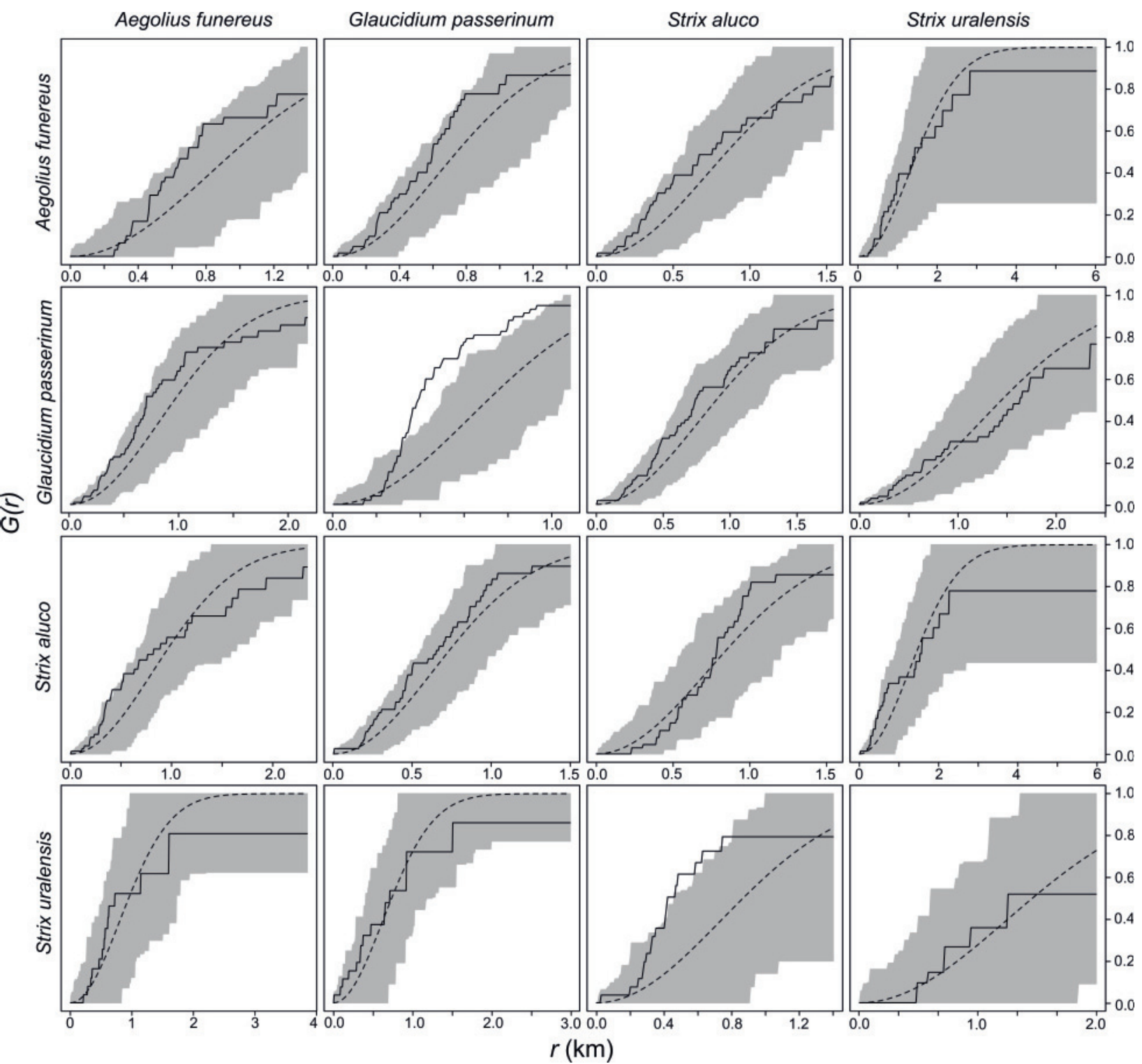

Fig. 3. Intra- and interspecific relationships between multitype (cross-type) nearest-neighbour distance distribution function ( $G(r))$ and the distances between locations with registered owls $(r$ in $\mathrm{km})$. Continuous line represents the observed function of species records, dashed line indicates theoretical null model expectations, and grey areas indicate the simulation envelopes generated from 499 Monte Carlo simulations under the null hypothesis of complete spatial randomness $(P \leq 0.004)$.

Obr. 3. Vnútro- a medzidruhové vzt'ahy medzi multitypovou (cross-type) distribučnou funkciou vzdialenosti najbližšieho suseda ( $G(r)$ ) a vzdialenost’ami medzi lokalitami so zaznamenanými sovami $(r, v \mathrm{~km})$. Súvislá čierna čiara predstavuje pozorovanú funkciu zaznamenaných jedincov sov, prerušovaná čiara predstavuje očakávaný teoretický nulový model a sivé plochy naznačujú simulované obaly vygenerované zo 499 Monte Carlo simulácií pri nulovej hypotéze úplnej priestorovej náhodnosti $(P \leq 0.004)$. 

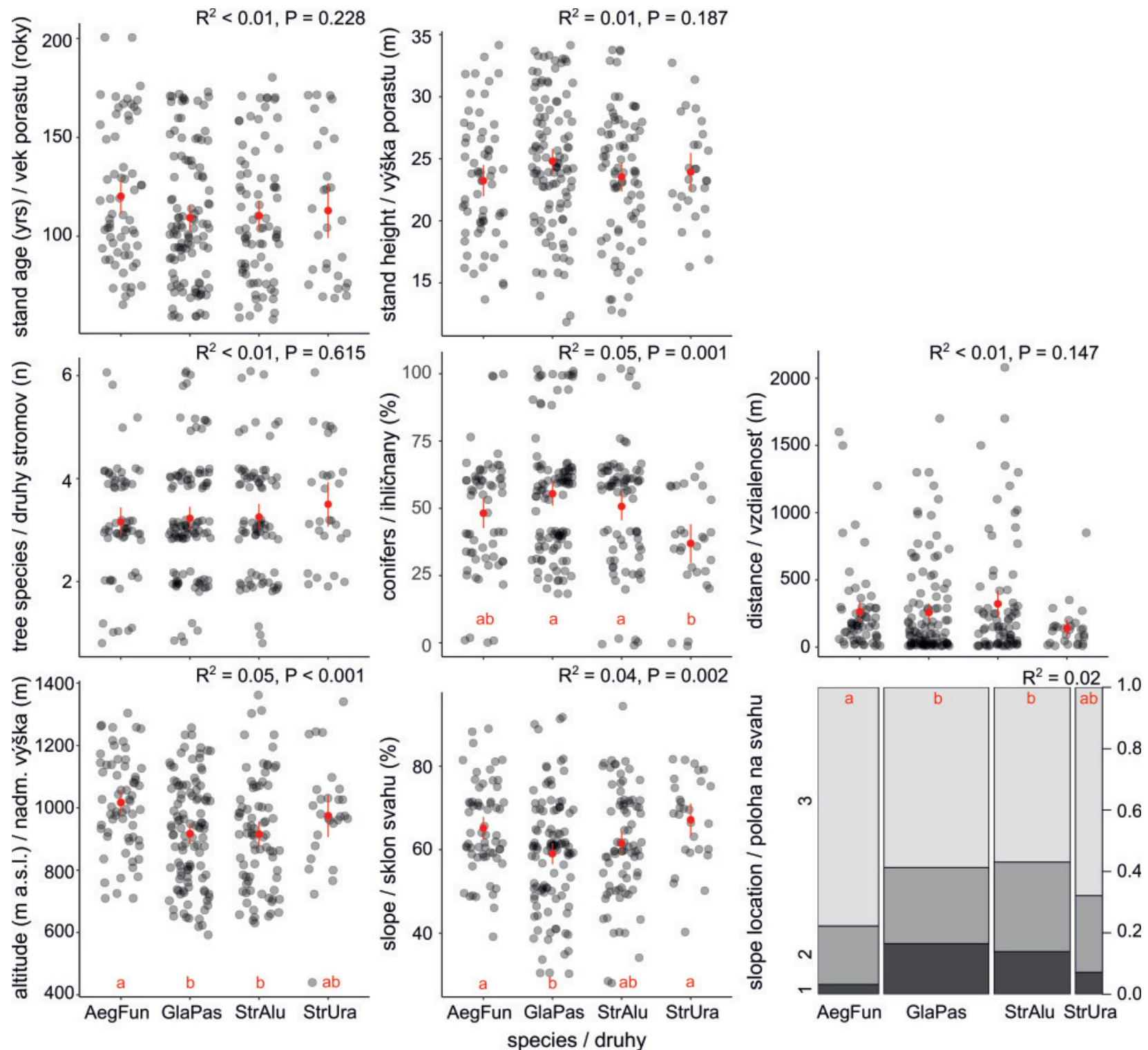

Fig. 4. Means and $95 \%$ confidence intervals of habitat characteristics assessed for locations of calling owls (AegFun = Aegolius funereus, GlaPas = Glaucidium passerinum, StrAlu = Strix aluco, StrUra $=$ Strix uralensis) in the Vel'ká Fatra Mts: stand age (years), stand height $(m)$, tree species richness $(n)$, proportion of coniferous tree species $(\%)$, distance to closest open area $(m)$, altitude $(m$ a.s.I.), slope (gradient; \%) and location of calling owl on hillslope (ordinal: $0=$ toeslope, $1=$ footslope, $2=$ backslope, $3=$ shoulder and summit). Points are jittered to minimise their overlapping.

Obr. 4. Priemery a $95 \%$-né intervaly spol'ahlivosti habitatových charakteristík zist'ovaných pre stanovištia volajúcich sov (AegFun = Aegolius funereus, GlaPas = Glaucidium passerinum, StrAlu = Strix aluco, StrUra = Strix uralensis) vo Vel'kej Fatre: vek porastu (roky), výška porastu $(\mathrm{m})$, počet druhov stromov $(\mathrm{n})$, zastúpenie ihličnatých drevín (\%), vzdialenost' od najbližšej otvorenej plochy $(\mathrm{m})$, nadmorská výška (m n. m.), sklon svahu (\%), a poloha volajúcej sovy vo svahu (rádové kategórie: $0=$ úpätie svahu, $1=$ dolná tretina svahu, 2 = stredná čast' svahu, 3 = horná tretina svahu a hrebeň). Body sú zobrazené tak, aby sa minimalizovalo ich prekrývanie.

Kloubec et al. 2015, Barbaro et al. 2016). Ural owls were not registered in pure coniferous stands in our study area, which is in accordance with the usual habitat selection of Ural owls in central Europe, where it is confined to deciduous forests, especially of European beech, in mountain areas (Marks et al. 1999, Kloubec et 
al. 2015). In most of its range in Slovakia the boreal owl inhabits old forests situated at the ends of valleys, neighbouring with open habitats such as meadows, grassy uplands and clearcuts (Pačenovský 2002b).

Our results appear to contradict the findings of other studies analyzing patterns of coexistence of at least two of the owl species investigated in our study. Negative association between sympatric Ural owls and tawny owls resulting in habitat displacement effect was observed in southern Poland (Kajtoch et al. 2015, 2016). These researchers found that tawny owls occupied forests with higher canopy compactness, sites located closer to forest boundaries and to built-up areas, as well as stands with a higher share of fir and spruce and a lower share of beech compared to sites occupied by the dominant Ural owls (Kajtoch et al. 2015). Similarly, competitive exclusion of tawny owls by Ural owls was observed in Slovenia, resulting in altitudinal segregation of the smaller and less competitive tawny owl to lower elevations than the Ural owl (Vrezec \& Tome 2004b). These authors explained this pattern of distribution in terms of different reactions by both species to human presence, as well as their habitat structure: Ural owls avoided lower altitudes with the presence of human settlements. In their studied area, boreal owls did not show negative interactions with Ural owls, and they inhabited similar habitats (Vrezec \& Tome 2004a). In contrast, the presence of Ural owls negatively affected the abundance of boreal owls in central Finland (Hakkarainen \& Korpimäki 1996). On the other hand, due to negative interactions boreal owls and tawny owls were highly segregated with regard to habitat and space in the Slovenian study area (Vrezec \& Tome 2004a). However, negative association between these two species was not found in submontane hilly areas in the Polish Carpathians and their surroundings, as the arrangement of boreal owl territories was random with respect to the tawny owl, and similarly the distribution of pygmy owl territories with respect to the Ural owl (Kajtoch et al. 2016). The authors explained this discrepancy in terms of the close proximity of boreal owls to Ural owls, which provided protection for the boreal owls, so the distance to tawny owls might be of secondary importance. Boreal owls, despite being the interspecific competitor and intraguild predator, did not affect the spatial arrangement of pygmy owls in Finland (Morosinotto et al. 2017).

Using spatial point pattern analysis, we did not detect any negative spatial associations within and between the four owl species. Habitat availability and quality might be responsible for discrepancies between studies in the observed spatial patterns of the owls' distribution. Thus more pronounced intra- and interspecific intraguild predation and competition can be expected in landscapes with lower availability of optimal nesting habitats and sites, and when food supply is limited (e.g. Hakkarainen \& Korpimäki 1996, Dhondt 2010, Barbaro et al. 2016, Morosinotto et al. 2017, Baroni et al. 2020). The fragmented forests in submontane hilly areas of the Polish Carpathians were occupied by the Ural owl at relatively low densities (Kajtoch et al. 2015, 2016), so negative interactions between the two species, i.e. avoidance behaviour by tawny owls in response to Ural owls leading to decreased tawny owl density, were relatively weak there (Kajtoch et al. 2015, 2016). In the boreal forests of Finland, pygmy owls' avoidance of their conspecifics, when choosing their breeding site, decreased when food was abundant, suggesting that high food availability leads to weaker intraspecific density dependence, probably through decrease in territory size (Morosinotto et al. 2017). Food resources are scarcer in boreal forest ecosystems compared to more southern temperate environments, which is reflected in the pygmy owl's larger home range size at the northern edge of its area of occurrence (Morosinotto et al. 2017). In addition, the numbers of competitors and predators present within the area also affect habitat availability (Dhondt 2010). In a relatively stable bird community, due to coexistence mechanisms the effects of competition on populations are practically impossible to determine without an experiment in which one competing species is removed, and then the response of the other is observed (Newton 1998, 2007). Well-developed coexistence mechanisms in stable bird communities may also be responsible for low intraguild predation, assessed based on analysis of more than 68,000 tawny owl food items collected mostly in central Slovakia, where only nine instances of boreal owl and three of pygmy owl consumed by tawny owls were found (Obuch 2011).

As the Ural owl is known to prey on the tawny owl (Mikkola 1983), the attraction of the former to the latter should be regarded as a consequence of interference and aggressive behaviour of the dominant species toward the subdominant, i.e. aggressiveness of Ural owls towards tawny owls (Pačenovský 1995, Vrh \& Vrezec 2006). This explanation may be supported by the random distribution of calling tawny owl locations in response to Ural owls, when due to their high density tawny owls cannot spatially avoid the Ural owls. The presence of calling pygmy owl males closer to conspecifics might 
be due to their preference for high-quality nest sites, and due to spatial clustering in the distribution of pygmy owl prey (Cornulier \& Bretagnolle 2006). Voles, the most common prey of the four owl species (Obuch 2011), are clustered in small patches during decreasing phases of the population cycle (Hakkarainen et al. 1997), which might restrict the territory locations available to pygmy owls. In addition, stronger territoriality expressed by behavioural responses such as approaching neighbour conspecifics could explain the observed pattern of pygmy owl spatial aggregation. Clustering of calling owls cannot be interpreted as a sign of positive interaction, as facilitation cannot be expected from territorial birds during the breeding season (Newton 1998).

Assessed response variable is a factor which can influence the observed spatial distribution pattern of intraguild predators and competitors. We monitored the locations of calling owl males in the present study, similarly as Vrezec \& Tome (2004a, b) and Kajtoch et al. $(2015,2016)$; locations of nests were surveyed for instance by Cornulier \& Bretagnolle (2006), Morosinotto et al. (2017) and Rebollo et al. (2017). Level of territory defence behaviour by owls may differ in response to intruder location within the territory (Pačenovský 1995). Territorial behaviour of Ural owls towards tawny owls was confirmed using a playback experiment (Vrh \& Vrezec 2006). Tawny owls vocalize more often in the peripheries than in the centre of their territory and home range (Sunde \& Bølstad 2004, Burgos \& Zuberogoitia 2018), and moreover their territories or home ranges can overlap (Burgos \& Zuberogoitia 2018, Peri 2018b). On the other hand, boreal owl males usually utter their primary song from within $100 \mathrm{~m}$, and frequently within $10 \mathrm{~m}$ of a suitable nest-cavity, but they may use several breeding sites during one season (Korpimäki \& Hakkarainen 2012). It can be assumed therefore that the results of studies dealing with different response variables will vary. Moreover, studies assessing calling bird location as a response variable may be more inaccurate when disentangling spatial interactions between owls, compared to the studies analysing the positions of nests.

Another factor which could affect the results of studies using the location of calling owls as a response variable is the detected proportion of the population. Correct territory mapping requires that birds must be sufficiently vocal to allow the location of their vocalizations to be pinpointed (Mennill 2011). Vocal activity of owls depends on many factors, e.g. species (Zuberogoitia \& Campos 1998), environmental factors (Ševčík et al. 2019, Zuberogoita et al. 2019), time of day and year (Zuberogoitia \& Campos 1998, Zuberogoita \& Martínez Climent 2000, Ševčík et al. 2019), population density (Zuberogoita \& Martínez Climent 2000, Salvati et al. 2002, Zuberogoita et al. 2019), mating status (Korpimäki \& Hakkarainen 2012), prey abundance (Ševčík et al. 2019), occurrence of conspecific or heterospecific competitors (Lourenço et al. 2013, but see Ševčík et al. 2019), number of researcher visits (Vrezec \& Bertoncelj 2018, Zuberogoita et al. 2019) or vocal stimulation by playback (Zuberogoita \& Martínez Climent 2000, Vrezec \& Bertoncelj 2018). Playback broadcasting is recommended as a principal technique for owl monitoring (Zuberogoitia \& Campos 1998, Zuberogoita et al. 2019), however the use of particular owl-call broadcasting may draw those owls into otherwise unused areas as a reaction to the call broadcasts (Kissling et al. 2010), or in a high-density population it can lead to overestimation of the abundance of calling males (Salvati et al. 2002), which could also obscure the interpretation of data.

To summarize, in the present study we describe the spatial arrangement of calling males of four owl species living in sympatry using point pattern analysis. Except for the intraspecific distribution of pygmy owls and the interspecific distribution of Ural owls compared to tawny owls exhibiting positive associations, most interand intraspecific associations had random spatial patterns, which might suggest the presence of developed coexistence mechanisms within these owl species living in sympatry, which is also supported by the high quality habitat within the study area. The habitat requirements of the four species broadly overlapped. Our results appear to be in discrepancy with other studies dealing with spatial distribution patterns of the same owl species. The differences between studies may be a result of complex interactions between intra- and interspecific associations, as well as varying habitat quality and quantity, food availability and the owl species involved in those interactions on a landscape scale (see Dhont 2010, Morosinotto et al. 2017).

\section{References}

Baddeley AJ \& Turner R 2005: spatstat: An R package for analyzing spatial point patterns. Journal of Statistical Software 12(6): 1-42.

Baddeley A, Rubak E \& Turner R 2015: Spatial point patterns: methodology and applications with $\mathrm{R}$. Chapman and Hall/CRC Press, London

Barbaro L, Blache S, Trochard G, Arlaud C, de Lacoste 
N \& Kayser Y 2016: Hierarchical habitat selection by Eurasian pygmy owls Glaucidium passerinum in old-growth forests of the southern French Prealps. Journal of Ornithology 157: 333-342. DOI: 10.1007/ s10336-015-1285-3.

Baroni D, Korpimäki E, Selonen V \& Laaksonen T 2020: Tree cavity abundance and beyond: nesting and food storing sites of the pygmy owl in managed boreal forests. Forest Ecology and Management 460: 117818. DOI: 10.1016/j foreco.2019.117818.

Biely A, Bezák V, Elečko M, Gross P et al. 2002: Geological structure, 74-77. In: Miklós L et al. (eds), Landscape Atlas of the Slovak Republic. Ministry of Environment of the Slovak Republic, Bratislava \& Slovak Environmental Agency, Banská Bystrica

Burgos G \& Zuberogoitia I 2018: A telemetry study to discriminate between home range and territory size in tawny owls. Bioacoustics 29: 109-121. DOI: 10.1080/09524622.2018.1555717.

Connell J 1983: On the prevalence and relative importance of interspecific competition: evidence from field experiments. American Naturalist 122 (5): 661-696. DOI: 10.1086/284165.

Cornulier T \& Bretagnolle V 2006: Assessing the influence of environmental heterogeneity on bird spacing patterns: a case study with two raptors. Ecography 29: 240-250. DOI: 10.1111/j.2006.09067590.04287.x.

Dhondt AA 2010: Effects of competition on great and blue tit reproduction: intensity and importance in relation to habitat quality. Journal of Animal Ecology 79: 257-265. DOI: 10.1111/j.13652656.2009.01624.x.

Faško P \& Št’astný P 2002: Mean annual precipitation totals, 99. In: Miklós L et al. (eds.), Landscape Atlas of the Slovak Republic. Ministry of Environment of the Slovak Republic, Bratislava \& Slovak Environmental Agency, Banská Bystrica

Fletcher R \& Fortin MJ 2018: Spatial ecology and conservation modeling. Springer, Cham. DOI: 10.1007/978-3-030-01989-1_4.

Fox J \& Weisberg S 2019: An $\bar{R}$ companion to applied regression. $3^{\text {rd }}$ ed. Sage, Thousand Oaks, CA.

Google 2020. Vel'ká Fatra. CNES / Airbus, Google, Maxar Technologies. Google Earth Pro 7.3.3.7699. Retrieved June 13, 2020.

Hagemeijer EJM \& Blair MJ (eds) 1997: The EBCC atlas of european breeding birds. Their distribution and abundance. T \& A D Poyser, London.
Hakkarainen H \& Korpimaki E 1996: Competitive and predatory interactions among raptors: an observational and experimental study. Ecology 77: 1134-1142.

Hakkarainen HV, Koivunen \& Korpimäki E 1997: Reproductive success and parental effort of Tengmalm's owls: Effects of spatial and temporal variation in habitat quality. Ecoscience 4: 35-42.

Henrioux PJD, Henrioux WP \& Chopard G 2003: Effects of forest structure on the ecology of pygmy owl Glaucidium passerinum in the Swiss Jura Mountains. Vogelwelt 124: 309-312.

Holm SR, Noon BR, Wiens JD \& Ripple WJ 2016: Potential trophic cascades triggered by the barred owl range expansion. Wildlife Society Bulletin 40: 615-624. DOI: 10.1002/wsb.714.

Hothorn T, Hornik K, van de Wiel M, Winell H \& Zeileis A 2017: Package 'coin' 1.2-1. Conditional inference procedures in a permutation test framework. Retrieved January 24, 2018, from http:// coin.r-forge.r-project.org/.

Jackman S 2017: pscl: Classes and methods for $\mathrm{r}$ developed in the political science computational laboratory. United States Studies Centre, University of Sydney. Sydney, New South Wales, Australia. R package version 1.5.2. Retrieved January 24, 2018, from https://github.com/atahk/pscl/.

Jenkins JM, Lesmeister DB, Wiens JD, Kane JT, Kane VR \& Verschuyl J 2019: Three-dimensional partitioning of resources by congeneric forest predators with recent sympatry. Scientific Reports 9(1): 1-10. DOI: 10.1038/s41598-019-42426-0.

Kajtoch Ł, Żmihorski M \& Wieczorek P 2015: Habitat displacement effect between two competing owl species in fragmented forests. Population Ecology 57: 517-527. DOI: 10.1007/s10144-015-0497-y.

Kajtoch , Matysek M \& Figarski T 2016: Spatiotemporal patterns of owl territories in fragmented forests are affected by a top predator (Ural owl). Annales Zoologici Fennici 53: 165-174.

Kissling ML, Lewis SB, \& Pendleton G 2010: Factors influencing the detectability of forest owls in Southeastern Alaska. Condor 112: 539-548. DOI: 10.1525/cond.2010.090217.

Kloubec B, Hora J, Št’astný K 2015: Ptáci jižních Čech. Jihočeský kraj, České Budějovice. [In Czech]

Korpimäki E \& Hakkarainen H 2012: The boreal owl: Ecology, behaviour and conservation of a forestdwelling predator. Cambridge University Press, Cambridge. 
König C \& Weick F 2008: Owls of the world. $2^{\text {nd }}$ ed. Christopher Helm, London.

LGIS 2020: Lesnícky geografický informačný systém [Forestry geographic information system]. NLC, Zvolen. Retrieved January 24, 2020, from http:// gis nlcsk.org/lgis/

Lourenço R, Goytre F, del Mar Delgado M, Thornton M, Rabaça JE \& Penteriani V 2013: Tawny owl vocal activity is constrained by predation risk. Journal of Avian Biology 44: 461-468. DOI: 10.1111/j.1600-048X.2013.00157.x.

Lourenço R, Penteriani V, Rabaça JE \& Korpimäki E 2014: Lethal interactions among vertebrate top predators: a review of concepts, assumptions and terminology. Biological Review 89: 270-283. DOI: 10.1111/brv.12054.

Lundberg A 1980: Why are the Ural owl Strix uralensis and the tawny owl $S$. aluco parapatric in Scandinavia? Ornis Scandinavica 11: 116-120.

Mangiafico S 2017: Package 'rcompanion' 1.10.1. Functions to support extension education program evaluation. Retrieved January 24, 2018, from http:// rcompanion.org/.

Marks JS, Cunnings RJ \& Mikkola H 1999: Family Strigidae (typical owls), 76-242. In: del Hoyo J, Elliot A \& Sargatal J (eds), Handbook of the birds of the world. Vol. 5, Barn owls to hummingbirds. Lynx Edicions, Barcelona.

Mennill DJ 2011: Individual distinctiveness in avian localizations and the spatial monitoring of behaviour. Ibis 153: 235-238. DOI: 10.1111/j.1474919X.2011.01119.x.

Mikoláš M, Ujházy K, Jasík M, Wiezik M, Gallay I, Polák P, Vysoký J, Čiliak M, Meigs GW, Svoboda M, Trotsiuk V \& Keeton WS 2019: Primary forest distribution and representation in a Central European landscape: Results of a large-scale fieldbased census. Forest Ecology and Management 449: 117466. DOI: 10.1016/j foreco.2019.117466.

Mikkola H 1976: Owls killing and killed by other owls and raptors in Europe. British Birds 69: 144-154.

Mikkola H 1983: Owls of Europe. T. \& A. D. Poyser, Calton.

Morosinotto C, Villers A, Thomson, RL, Varjonen R \& Korpimäki E 2017: Competitors and predators alter settlement patterns and reproductive success of an intraguild prey. Ecological Monographs 87: 4-20. DOI: $10.1002 / \mathrm{ecm} .1238$.

Newton I 1998: Population limitation in birds. Academic Press, San Diego \& London.
Newton I 2007: Population limitation in birds: the last 100 years. British Birds 100(9): 518.

Obuch J 2011: Spatial and temporal diversity of the diet of the tawny owl (Strix aluco). Slovak Raptor Journal 5: 1-120. DOI: 10.2478/v10262-012-0057-8.

Pačenovský S 1995: K medzidruhovým vzt’ahom Glaucidium passerinum, Strix uralensis a Strix aluco [On interspecific relationships between Glaucidium passerinum, Strix uralensis a Strix aluco]. Tichodroma 8: 61-73. [In Slovak with English summary]

Pačenovský S 2002a: Kuvičok vrabčí (Glaucidium passerinum) [Eurasian pygmy owl], 364-367. In: Danko Š, Darolová A \& Krištín A (eds), Rozšírenie vtákov na Slovensku [Birds distribution in Slovakia]. Veda, Bratislava. [in Slovak with English summary]

Pačenovský S 2002b: Pôtik kapcavý (Aegolius funereus) [The Tengmalm's owl], 379-381 In: Danko Š, Darolová A \& Krištín A (eds), Rozšírenie vtákov na Slovensku [Birds distribution in Slovakia]. Veda, Bratislava. [in Slovak with English summary]

Peri A 2018a: A comparison of three methods for planning a census of tawny owl (Strix aluco) populations living at high territorial density. Bioacoustics 27: 245-260. DOI: 10.1080/ 09524622.2017 .1326164$.

Peri A 2018b: Censusing a tawny owl (Strix aluco) population living at high density merging two consolidated techniques. Écoscience 25: 249-257. DOI: $10.1080 / 11956860.2018 .1455370$.

Polis GA, Myers CA \& Holt RD 1989: The ecology and evolution of intraguild predation: potential competitors that eat each other. Annual Review of Ecology and Systematics 20: 297-330.

R Core Team 2020: R: A language and environment for statistical computing. R Foundation for Statistical Computing, Vienna. Retrieved January 24, 2020, from https://www.R-project.org/.

Rebollo S, Martínez-Hesterkamp S, García-Salgado G, Pérez-Camacho L, Fernández-Pereira JM \& Jenness J 2017: Spatial relationships and mechanisms of coexistence between dominant and subordinate top predators. Journal of Avian Biology 48: 1226-1237. DOI: $10.1111 /$ jav.01337.

Salvati L, Manganaro A \& Ranazzi L. 2002. Wood quality and the tawny owl Strix aluco in different forest types of central Italy. Ornis Svecica 12: 4751.

Schoeneberger PJ, Wysocki DA, Benham EC \& Soil 
Survey Staff 2012: Field book for describing and sampling soils. Version 3.0. U.S. Department of Agriculture, Natural Resource Conservation Service, Lincoln, NE.

Sergio F, Marchesi L \& Pedrini P 2003: Spatial refugia and the coexistence of a diurnal raptor with its intraguild owl predator. Journal of Animal Ecology 72: 232-245. DOI: 10.1046/j.1365-2656.2003. 00693.x.

Sergio F \& Hiraldo F 2008: Intraguild predation in raptor assemblages: a review. Ibis 150: 132-145. DOI: 10.1111/j.1474-919X.2008.00786.x.

Sergio F, Marchesi L, Pedrini P \& Penteriani V 2007: Coexistence of a generalist owl with its intraguild predator: distance-sensitive or habitat-mediated avoidance? Animal Behaviour 74: 1607-1616. DOI: 10.1016/j.anbehav.2006.10.022.

Solonen T 1994: Factors affecting the structure of Finnish birds of prey communities. Ornis Fennica 71: 156-169

Ševčík R, Riegert J, Šindelář J \& Zárybnická M 2019: Vocal activity of the Central European boreal owl population in relation to varying environmental conditions. Ornis Fennica 96: 1-12.

Sih A, Crowley P, McPeek M, Petranka J \& Strohmeier K 1985: Predation, competition, and prey communities: a review of field experiments. Annual Review of Ecology and Systematics 16: 269-311.

Šotnár K, Pačenovský S \& Obuch J 2015: On the food of the Eurasian pygmy owl (Glaucidium passerinum) in Slovakia. Raptor Journal 9: 115-126. DOI: $10.1515 /$ srj-2015-0009.

Št’astný P, Nieplová E \& Melo M 2002: Mean annual air temperature, 98. In: Miklós L et al. (eds), Landscape atlas of the Slovak Republic. Ministry of Environment of the Slovak Republic, Bratislava \& Slovak Environmental Agency, Banská Bystrica

Suhonen J, Halonen M, Mappes T \& Korpimäki E 2007: Interspecific competition limits larders of pygmy owls Glaucidium passerinum. Journal of Avian Biology 38: 630-634. DOI: 10.1111/j. 2007.0908-8857.03960.x.

Sunde P \& Bølstad MS 2004: A telemetry study of the social organization of a tawny owl (Strix aluco) population. Journal of Zoology 263: 65-76. DOI: 10.1017/S0952836904004881.
Townsend CR, Begon M \& Harper JL 2008: Essentials of ecology. $3^{\text {rd }}$ ed. Blackwell Science, Oxford.

Venables WN \& Ripley BD 2002: Modern applied statistics with S. $4^{\text {th }}$ ed. Springer, New York.

Vrezec A \& Bertoncelj I 2018: Territory monitoring of tawny owls Strix aluco using playback calls is a reliable population monitoring method. Bird Study 65 (suppl. 1): S52-S62.

Vrezec A \& Mihelič T 2013: The Ural owl, Strix uralensis macroura, in Slovenia: an overview of current knowledge on species ecology. Rivista Italiana di Ornitologia 82: 30-37.

Vrezec A \& Tome D 2004a: Habitat selection and patterns of distribution in a hierarchic forest owl guild. Ornis Fennica 81: 109-118.

Vrezec A \& Tome D 2004b: Altitudinal segregation between Ural owl Strix uralensis and tawny owl $S$. aluco: evidence for competitive exclusion in raptorial birds. Bird Study 52: 264-269. DOI: 10.1080/00063650409461362.

Vrh P \& Vrezec A 2006: Interspecific territorial vocal activity of the Ural owl (Strix uralensis) towards tawny owl (Strix aluco), sympatric owl competitor: a playback experiment. Razprave Razreda SAZU 47: 99-105.

Wickham H, Chang W \& RStudio 2016: Package 'ggplot2' 2.2.1. create elegant data visualisations using the grammar of graphics. Retrieved January 24, 2017, from http://ggplot2.tidyverse.org/.

Zuberogoitia I \& Campos LF 1998: Censusing owls in large areas: a comparison between methods. Ardeola 45: 47-53.

Zuberogoitia I \& Martínez JA 2000: Methods for surveying tawny owl Strix aluco populations in large areas. Biota 1: 79-88.

Zuberogoitia I, Martinez JA, Zabala J \& Martínez JE 2005: Interspecific aggression and nest-site competition in a European owl community. Journal of Raptor Research 39: 156-159.

Zuberogoitia I, Burgos G, González-Oreja JA, Morant J, Martínez JE \& Zabala Albizua J 2019: Factors affecting spontaneous vocal activity of tawny owls Strix aluco and implications for surveying large areas. Ibis 161: 495-503. DOI: 10.1111/ibi.12684.

Received 31. 5. 2020 Accepted 24. 8. 2020 